Japan Collection of

Microorganisms, RIKEN (The Institute of Physical and Chemical Research), Wako, Saitama 351-0198, Japan

\section{Bannoa hahajimensis gen. nov., sp. nov., and three related anamorphs, Sporobolomyces bischofiae sp. nov., Sporobolomyces ogasawarensis sp. nov. and Sporobolomyces syzygii sp. nov., yeasts isolated from plants in Japan}

\author{
Makiko Hamamoto, Vu Nguyen Thanh and Takashi Nakase \\ Author for correspondence: Makiko Hamamoto. Tel: +8148467 9560. Fax: +81484624617 \\ e-mail: hamamoto@jcm.riken.go.jp
}

\begin{abstract}
Fourteen ballistoconidium-forming yeast strains were isolated from leaves of plants collected in the Ogasawara Islands, which are isolated islands in the Pacific Ocean, about $1000 \mathrm{~km}$ south of the Japanese mainland, in the subtropical zone. The 14 isolates were characterized by the absence of xylose in whole-cell hydrolysates, the presence of $Q-10\left(\mathrm{H}_{2}\right)$ as the major ubiquinone isoprenologue, $\mathrm{G}+\mathrm{C}$ contents of $47.6-52.0 \mathrm{~mol} \%$, the inability to ferment sugars or to assimilate nitrate and positive Diazonium blue $B$ and urease reactions. They formed a phylogenetically coherent cluster within the Erythrobasidium lineage in the Urediniomycetes of the Basidiomycota based on 185 rDNA sequences. Analyses of the nucleotide sequences of internal transcribed spacer regions and DNA complementarity showed that four genospecies were recognized among the 14 isolates. A mating reaction was observed in one of the four genospecies, which produced one-celled basidia on dikaryotic hyphae with clamp connections. On the basis of the morphological, physiological, chemotaxonomic and phylogenetic analyses, a new teleomorphic genus, Bannoa, is proposed, in which one novel species is described, Bannoa

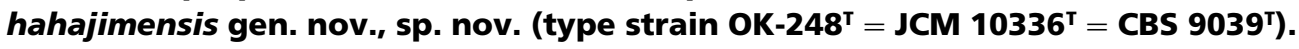
The other three anamorphic genospecies are described as Sporobolomyces bischofiae sp. nov. (type strain OK-257' $=$ JCM 10338 ${ }^{\top}=$ CBS 9041 ${ }^{\top}$ ), Sporobolomyces ogasawarensis sp. nov. (type strain OK-14 ${ }^{\top}=\mathrm{JCM} 10326^{\top}=\mathrm{CBS}^{\mathrm{T}}$ $9^{9038^{\top}}$ ) and Sporobolomyces syzygii sp. nov. (type strain $0 K-227^{\top}=J^{\top} \mathrm{CM} 10337^{\top}$ $=$ (BS 9040').
\end{abstract}

Keywords: Bannoa hahajimensis gen. nov., sp. nov., Sporobolomyces, ballistoconidium-forming yeast, 18S rDNA, ITS

\section{INTRODUCTION}

The two species Erythrobasidium hasegawianum Hamamoto, Sugiyama \& Komagata 1991 and Sporobolomyces elongatus Shivas \& Rodrigues de Miranda 1983 are the only known basidiomycetous yeasts with the hydrogenated Q-10 Q-10 $\left(\mathrm{H}_{2}\right)$ as the major ubiquinone

Abbreviation: ITS, internal transcribed spacer.

The DDBJ accession numbers for the 185 rDNA and the internal transcribed spacer sequences obtained in this study are given in Table 1. isoprenologue (Yamada \& Kondo, 1973; Yamada et al., 1973; Nakase \& Suzuki, 1986). So far, only one strain has been assigned to each species (Boekhout \& Nakase, 1998; Sugiyama \& Hamamoto, 1998). Erythrobasidium hasegawianum was isolated from an old culture of beer yeast (Robbins \& Ma, 1944) and Sporobolomyces elongatus was isolated from the surface of a leaf of Callistemon viminalis (Soland ex Gaertn.) G. Don ex Loud. in Australia (Shivas \& Rodrigues de Miranda, 1983). Since the isolation of these two strains with Q-10 $\left(\mathrm{H}_{2}\right)$, no additional basidiomycetous yeasts with the unique ubiquinone isopre- 
nologue have been found, in spite of our intensive survey of basidiomycetous yeasts from plant samples in various regions.

Recently, we found a third yeast strain containing Q$10\left(\mathrm{H}_{2}\right)$, from a leaf collected in China, and described a novel species of the genus Sporobolomyces, Sporobolomyces yunnanensis (Bai et al., 2001). Subsequently, we isolated 14 strains of undescribed ballistoconidiumforming yeasts containing Q- $10\left(\mathrm{H}_{2}\right)$ from leaves in the Ogasawara Islands, which are isolated islands in the Pacific Ocean, about $1000 \mathrm{~km}$ south of the Japanese mainland, in the subtropical zone. The strains were characterized by their inability to assimilate nitrate and formed a phylogenetically coherent cluster within the Erythrobasidium lineage in the Urediniomycetes of the Basidiomycota. Of these 14 isolates, four had the ability to mate between compatible mating types and produced one-celled basidia on dikaryotic hyphae with clamp connections. In this paper, we report the taxonomic characterization and classification of the 14 isolates and propose the new teleomorphic genus Bannoa, with Bannoa hahajimensis gen. nov., sp. nov., and three novel Sporobolomyces species, Sporobolomyces bischofiae sp. nov., Sporobolomyces ogasawarensis sp. nov. and Sporobolomyces syzygii sp. nov.

\section{METHODS}

Yeast isolation and cultivation. Samples of dead leaves of six plant species were collected on Chichi-jima and Haha-jima Islands of the Ogasawara Islands, Japan. The procedure used for yeast isolation and purification has been described previously (Nakase \& Suzuki, 1985; Nakase \& Takashima, 1993). All strains were grown at 17 or $25^{\circ} \mathrm{C}$ in yeast extract/malt extract broth or yeast extract/malt extract agar (Difco) for purification and cultivation. The strains used in this study are listed in Table 1.

Morphological, physiological and biochemical characteristics. The methods for morphological, physiological, biochemical and chemotaxonomic characterization and DNA-DNA reassociation experiments were described previously (Hamamoto \& Nakase, 1995). The mating experiment was performed according to the method described by Yarrow (1998). The mating phenomenon was observed with a light microscope and Hitachi S-2400 scanning electron microscope. Specimens for scanning electron microscopy were prepared as described by Itoh et al. (1989). The staining of nuclei was carried out as described previously (Hamamoto et al., 1988).

Nucleotide sequence analyses. The method for genomic DNA extraction was described previously (Hamamoto et al., 2000). The primers used for the amplification and sequencing of $18 \mathrm{~S}$ rDNA and the internal transcribed spacer (ITS) region were those described by White et al. (1990). The PCR products were sequenced using an ABI Prism BigDye Terminator cycle sequencing ready reaction kit (Applied Biosystems). Analyses of DNA sequence reactions were performed with an Applied Biosystems model 310 sequencer. Sequences were aligned using CLUSTAL W version 1.81 (Thompson et al., 1994) and were adjusted manually. Evolutionary distances were calculated using the program DNADIST of PHYLIP version 3.57c (Felsenstein, 1995) with Kimura's two-parameter model and trees were constructed in NEIGHBOR by the neighbour-joining method (Saitou \& Nei, 1987). The confidence values of branches were determined by performing a bootstrap analysis (Felsenstein, 1985) with 1000 replicates. The sequences determined were deposited in the DDBJ database under the accession numbers shown in Table 1.

\section{RESULTS}

\section{Morphological, physiological and chemotaxonomic characteristics}

The 14 isolates formed ballistoconidia whose shape was asymmetric. They did not form hyphae or pseudohyphae on yeast extract/malt extract agar, potato dextrose agar or corn meal agar (Difco) and the colonies were orange to salmon-red in colour. Sugars were not fermented, starch-like substances were not produced and nitrate was not assimilated. The assimilation patterns are given below in the descriptions of the four novel species. Diazonium blue B and urease reactions were positive. All the isolates contained Q$10\left(\mathrm{H}_{2}\right)$ as the major ubiquinone isoprenologue and xylose was absent from whole-cell hydrolysates. The $\mathrm{G}+\mathrm{C}$ contents of the DNA of the isolates ranged from $47 \cdot 6$ to $52.0 \mathrm{~mol} \%$, as shown in Table 1 . The values for the type strains of Erythrobasidium hasegawianum and Sporobolomyces elongatus were respectively 50.0 and $55 \cdot 0 \mathrm{~mol} \%$.

\section{Nucleotide sequence analyses}

The nucleotide sequences of ITS regions of the 17 strains shown in Table 1 were determined to clarify the relationships between them. The unrooted dendrogram in Fig. 1 was constructed from datasets aligned by CLUSTAL $\mathrm{W}$ version 1.81 on the basis of 148 (ITS1) and 211 (ITS2) sites. Our 14 isolates were separated clearly from the three known species that contain Q$10\left(\mathrm{H}_{2}\right)$. These isolates were divided into four major clusters in the ITS-based dendrogram. Strains OK$227^{\mathrm{T}}$ and $\mathrm{OK}-257^{\mathrm{T}}$ were placed independently in the ITS-based dendrogram. The levels of sequence similarity of the ITS regions of strains OK-52, OK-173, $\mathrm{OK}-219$ and $\mathrm{OK}-248^{\mathrm{T}}$ were $100 \%$, and these isolates formed a tight phylogenetic cluster in the ITS-based dendrogram with a high bootstrap value $(100 \%)$. Strains OK-1, OK-14 ${ }^{\mathrm{T}}$, OK-19, OK-21, OK-38, OK39, OK-166 and OK-198 formed another tight phylogenetic cluster in the ITS-based dendrogram, with a high bootstrap value $(99 \%)$. The levels of sequence similarity of the ITS region of the eight strains ranged from $97 \cdot 2$ to $100 \cdot 0 \%$.

Analysis of $18 \mathrm{~S}$ rDNA sequences revealed that 13 of our 14 isolates had introns, which were considered to be group I introns with conserved sequence elements $\mathrm{P}$, Q, R and S (Cech, 1988). Single introns were found in strains OK-1, OK-14 ${ }^{\mathrm{T}}$, OK-19, OK-21, OK-38, OK39, OK-166, OK-198 (all $382 \mathrm{nt}$ ), OK-52, OK-173, OK-219, OK-248 (all $328 \mathrm{nt}$ ) and OK-257 ${ }^{\mathrm{T}}$ (total of $687 \mathrm{nt})$. Strain OK $-257^{\mathrm{T}}$ contained introns of 297 and $390 \mathrm{nt}$, in separate locations. 
Table 1. Strains used in this study and their DNA base composition

Haha-jima and Chichi-jima are islands in the Ogasawara Islands, Japan.

\begin{tabular}{|c|c|c|c|c|}
\hline Strain & Isolate no. & Source & $\begin{array}{c}G+C \text { content } \\
((\mathrm{mol} \%)\end{array}$ & Accession no. \\
\hline \multicolumn{5}{|l|}{ Bannoa hahajimensis } \\
\hline JCM 10333 & OK-52 & Dead leaves of Bryophyllum pinnatum, Haha-jima & $47 \cdot 8$ & AB035894 \\
\hline JCM 10334 & OK-173 & Dead leaves of Rhaphiolepis wrightiana, Haha-jima & $48 \cdot 0$ & AB035895 \\
\hline JCM 10335 & OK-219 & Dead leaves of Syzygium buxifolium, Haha-jima & $47 \cdot 6$ & AB035896 \\
\hline $\mathrm{JCM} 10336^{\mathrm{T}}$ & $\mathrm{OK}-248^{\mathrm{T}}$ & Dead leaves of Bryophyllum pinnatum, Haha-jima & $48 \cdot 1$ & AB035897 \\
\hline $\begin{array}{l}\text { Sporobolomyces bischofiae } \\
\text { JCM } 10338^{\mathrm{T}}\end{array}$ & $\mathrm{OK}-257^{\mathrm{T}}$ & Dead leaves of Bischofia javanica, Chichi-jima & $49 \cdot 6$ & AB035721 \\
\hline \multicolumn{5}{|l|}{ Sporobolomyces ogasawarensis } \\
\hline JCM 10325 & OK-1 & Dead leaves of Osmanthus insularis, Chichi-jima & $51 \cdot 6$ & AB035712 \\
\hline JCM $10326^{\mathrm{T}}$ & $\mathrm{OK}-14^{\mathrm{T}}$ & Dead leaves of Schima mertensiana, Chichi-jima & $51 \cdot 5$ & AB035713 \\
\hline JCM 10327 & OK-19 & Dead leaves of Schima mertensiana, Chichi-jima & $51 \cdot 6$ & AB035714 \\
\hline JCM 10328 & OK-21 & Dead leaves of Schima mertensiana, Chichi-jima & $51 \cdot 5$ & AB035715 \\
\hline JCM 10329 & OK-38 & Dead leaves of Schima mertensiana, Chichi-jima & $51 \cdot 9$ & AB035716 \\
\hline JCM 10330 & OK-39 & Dead leaves of Schima mertensiana, Chichi-jima & $52 \cdot 0$ & AB035717 \\
\hline JCM 10331 & OK-166 & Dead leaves of Syzygium buxifolium, Chichi-jima & $51 \cdot 6$ & AB035718 \\
\hline JCM 10332 & OK-198 & Dead leaves of Syzygium buxifolium, Haha-jima & $52 \cdot 0$ & AB035719 \\
\hline $\begin{array}{l}\text { Sporobolomyces syzygii } \\
\text { JCM } 10337^{\mathrm{T}}\end{array}$ & $\mathrm{OK}-227^{\mathrm{T}}$ & Dead leaves of Syzygium buxifolium, Haha-jima & $48 \cdot 9$ & $\mathrm{AB} 035720$ \\
\hline $\begin{array}{l}\text { Erythrobasidium hasegawianum } \\
\text { JCM } 1545^{\mathrm{T}}\end{array}$ & - & IFO $1058^{\mathrm{T}}$ & $50 \cdot 0$ & AB036065 \\
\hline $\begin{array}{l}\text { Sporobolomyces elongatus } \\
\text { JCM 5354 }\end{array}$ & - & CBS $8080^{\mathrm{T}}$ & $55 \cdot 0$ & AB036066 \\
\hline $\begin{array}{l}\text { Sporobolomyces yunnanensis } \\
\text { JCM } 10687^{\mathrm{T}}\end{array}$ & - & $\mathrm{CH} 2.141^{\mathrm{T}}$ & $50 \cdot 0 *$ & AB030353 \\
\hline
\end{tabular}

* Data from Bai et al. (2001).

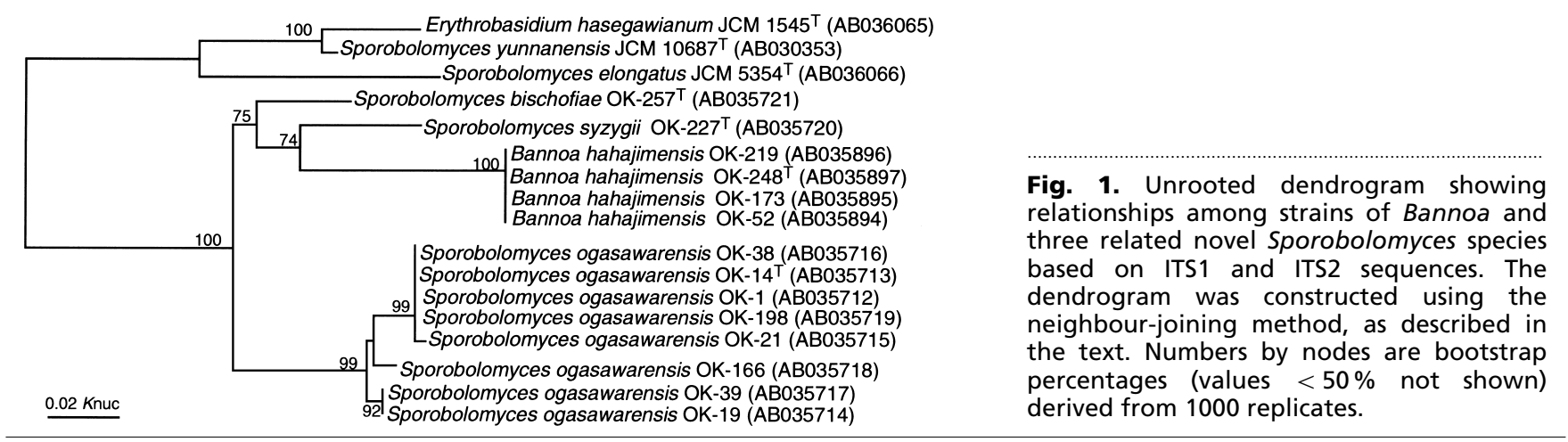

The 18S rDNA sequences of four isolates that were representative of each of the clusters from the ITSbased dendrogram, strains $\mathrm{OK}-14^{\mathrm{T}}$, OK-227 $7^{\mathrm{T}}$, OK$248^{\mathrm{T}}$ and $\mathrm{OK}-257^{\mathrm{T}}$, were aligned with 14 published sequences to define their phylogenetic positions within the basidiomycetes. Fig. 2 shows a phylogenetic tree constructed by the neighbour-joining method (Saitou $\&$ Nei, 1987) on the basis of the 1684 positions alignable in all the species examined here. All our isolates were placed in the Erythrobasidium lineage in the Urediniomycetes, together with Erythrobasidium hasegawianum, Rhodotorula lactosa, Rhodotorula minuta, Sakaguchia dacryoides and nine species that are currently classified in the genus Sporobolomyces, namely Sporobolomyces coprosmae, Sporobolomyces elongatus, Sporobolomyces foliicola, Sporobolomyces gracilis, Sporobolomyces kluyverinielii, Sporobolomyces oryzicola, Sporobolomyces phyllomatis, Sporo- 


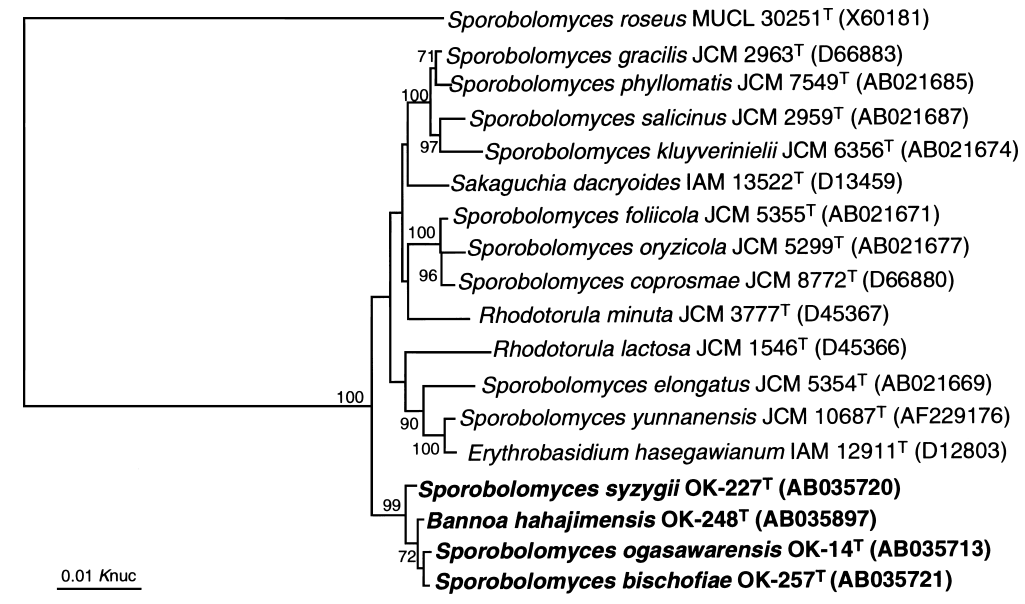

bolomyces salicinus and Sporobolomyces yunnanensis (Fig. 2). Our isolates formed a phylogenetically coherent cluster within the Erythrobasidium lineage, with a high bootstrap value $(99 \%)$.

\section{DNA-DNA reassociation}

Strain OK-248 $8^{\mathrm{T}}$ showed high degrees of relative binding (94-100\%) with strains OK-52, OK-173 and OK-219, but low degrees of binding (11-49\%) with strains $\mathrm{OK}-14^{\mathrm{T}}, \mathrm{OK}-227^{\mathrm{T}}$ and $\mathrm{OK}-257^{\mathrm{T}}$ and Erythrobasidium hasegawianum JCM $1545^{\mathrm{T}}$. Strain OK-14 showed high degrees of relative binding (76-100\%) with strains OK-1, OK-19, OK-21, OK-38, OK-39, OK-166 and OK-198, but low degrees of binding $(9-40 \%)$ with strains $\mathrm{OK}-227^{\mathrm{T}}$, OK- $248^{\mathrm{T}}$ and OK$257^{\mathrm{T}}$ and Erythrobasidium hasegawianum JCM $1545^{\mathrm{T}}$. Strains OK $-227^{\mathrm{T}}$ and OK $-257^{\mathrm{T}}$ showed low degrees of relative binding (15-49\%) with all the other novel isolates, Erythrobasidium hasegawianum JCM 1545 and each other.

\section{Sexual reproduction}

After $2-3$ days on yeast carbon base agar $[11.7 \mathrm{~g}$ yeast carbon base (Difco), $20 \mathrm{~g}$ agar, $1000 \mathrm{ml}$ distilled water] or corn meal agar (Difco), conjugation was observed between strains OK-52 and OK-173 (Fig. 3a, b), strains OK-173 and OK-219, strains OK-173 and OK$248^{\mathrm{T}}$ and strains OK-219 and OK-248 ${ }^{\mathrm{T}}$. Subsequently, dikaryotic mycelium with clamp connections developed (Fig. 3c). After 10 days, basidia developed laterally, were clamped at their base (Fig. 3d, e) and sometimes grew terminally. The basidia were obovate to dacryoid, $8.0-10 \cdot 0 \times 15 \cdot 0-20 \cdot 0 \mu \mathrm{m}$. They appeared to be diploid, as the size of their nuclei was twice that of nuclei in the dikaryotic mycelium (Fig. 3f, g). Germination of the basidia occurred by the formation of hyphae. These terminated with a slender apex, on which yeast cells originated laterally. The yeast cells were monokaryotic and the size of the nuclei was
Fig. 2. Phylogenetic positions of the type strains of Bannoa hahajimensis and three related novel Sporobolomyces species based on $18 \mathrm{~S}$ rDNA. The branching pattern was generated by the neighbour-joining method, as described in the text. Numbers by nodes are bootstrap percentages (values $<50 \%$ not shown) derived from 1000 replicates.
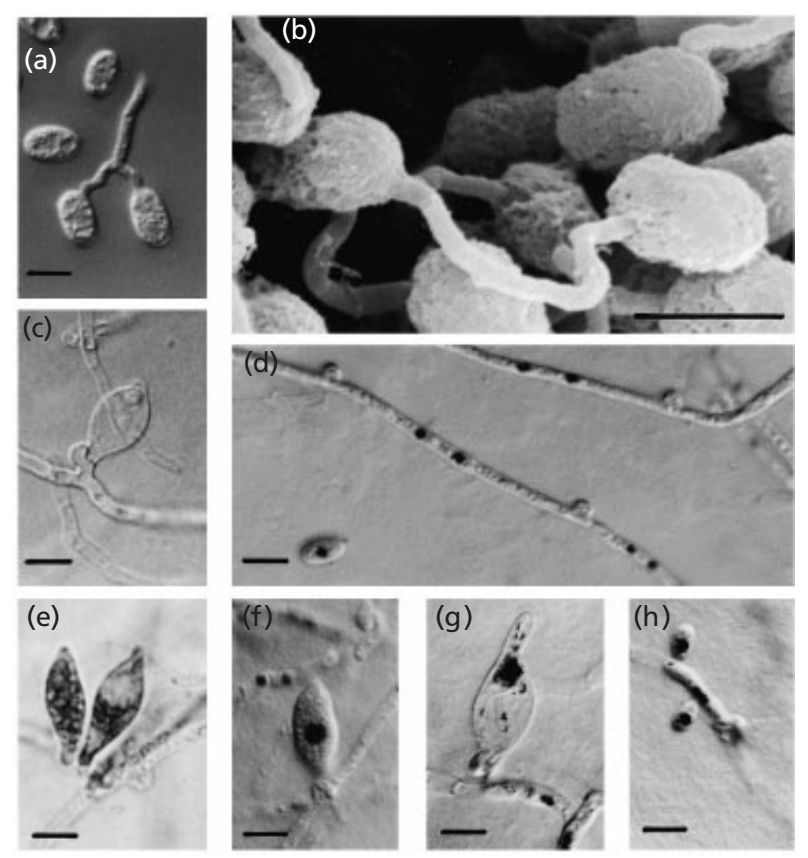

Fig. 3. Mating phenomenon in Bannoa hahajimensis. (a, b) A conjugated cell with a copulation tube (OK-52 $\times$ OK-173). (c, e) Basidia developed laterally, clamped at their base (c, OK$219 \times \mathrm{OK}^{-248^{\mathrm{T}}}$; e, OK-173 $\times$ OK-248 ${ }^{\mathrm{T}}$ ). (d) Dikaryotic hyphae (OK$173 \times$ OK-219). (f) Monokaryotic basidium (OK-173 $\times$ OK-248 ${ }^{\top}$ ). (g) Basidium developing hyphae for germination (OK-52 $\times$ OK173). (h) Yeast cells originating laterally on a hypha (OK$52 \times$ OK-173). Bars, $5 \mu \mathrm{m}$.

comparable to that of the nuclei in the dikaryophase or the solitary yeast phase (Fig. 3h).

\section{DISCUSSION}

The ITS region has been found to be useful in resolving relationships among closely related taxa, because of its high substitution rate compared with that of $18 \mathrm{~S}$ and 
26S rDNA (Berbee et al., 1995; Waalwijk et al., 1996; James et al., 1996; Oda et al., 1997; Nagahama et al., 1999; Hamamoto et al., 2000). To clarify the relationships among our isolates at the species level, the sequences of the ITS regions were determined and analysed. Strains OK $-227^{\mathrm{T}}$ and $\mathrm{OK}-257^{\mathrm{T}}$, which were clearly separated from any other isolates in the ITSbased dendrogram, were considered to represent single species. Strains OK-52, OK-173, OK-219 and OK$248^{\mathrm{T}}$ were considered to be members of a single species because their ITS sequences were identical. Some substitutions were found in the ITS sequences of strains OK-1, OK-14 ${ }^{\mathrm{T}}$, OK-19, OK-21, OK-38, OK39 , OK-166 and OK-198. However, the strains formed a coherent cluster in the ITS-based dendrogram, supported by a high bootstrap value ( $99 \%$ ), and they showed rather high similarities in ITS sequences $(97 \cdot 2-100 \cdot 0 \%)$. This suggests that these eight strains are members of a single species.

The levels of DNA complementarity confirmed that our 14 isolates belonged to four genospecies. The four species based on DNA-DNA reassociation experiments corresponded well with those suggested by the ITS-based dendrogram. The ITS sequence would be one of the important criteria for the discrimination of these yeast species.

As a result of the mating experiments, the genospecies comprising strains OK-52, OK-173, OK-219 and OK$248^{\mathrm{T}}$ was considered to be teleomorphic. Based on mating compatibility, three distinct mating types (A1, $\mathrm{A} 2$ and A3) have been detected in this genospecies: strain OK-248 ${ }^{\mathrm{T}}$ (mating type A1), strain OK-173 (mating type A2) and strains OK-52 and OK-219 (mating type A3). When intermated (A1 × A2, A2 × A3 and $\mathrm{A} 3 \times \mathrm{A} 1)$, all combinations gave complete life cycles, except the combination between strains OK-52 and $\mathrm{OK}-248^{\mathrm{T}}$. In this conjugated pair, conjugated cells with a copulation tube and hyphal development were detected, but the formation of diploid basidia was not observed. This may be due to some incompatibility. The multiallelic bipolar mating system observed in strains OK-52, OK-173, OK-219 and OK-248 ${ }^{\mathrm{T}}$ is similar to that described in Cystofilobasidium infirmominiatum (Fell et al., 1973) in the Hymenomycetes. Conjugation was not observed when any of the mating types was mixed with the other isolates.

The morphological and biochemical characters of our 14 isolates are consistent with the currently recognized description of the genus Sporobolomyces (Boekhout \& Nakase, 1998). However, the genus Sporobolomyces has been revealed to be polyphyletic, based on analysis of 18S rDNA sequences (Hamamoto \& Nakase, 2000). Specifically, Sporobolomyces species are placed in the Sporidiales, Agaricostilbum/Bensingtonia, Erythrobasidium and subbrunneus lineages in the Urediniomycetes. Our four genospecies formed a monophyletic cluster in the Erythrobasidium lineage, based on 18S rDNA sequences (Fig. 2). There are three species with different sexual life cycles in this lineage (Fell et al.,
2000). Erythrobasidium hasegawianum, which contains Q-10 $\left(\mathrm{H}_{2}\right)$, produces unicellular basidia without mating (Hamamoto et al., 1988). Occultifur externus, which contains Q-10 (determined in this study), produces four-celled auricularioid basidia after conjugation between two yeast cells (Sampaio et al., 1999). Sakaguchia dacryoides, which also contains Q-10, produces teliospores that germinate to give two to four-celled basidia with repetitively budding basidiospores after mating between the different mating pairs (bifactorial mating system) (Fell \& Statzell-Tallman, 1998). One of our four species has a mating system (the multiallelic bipolar mating system) that is unique in the Urediniomycetes, and it produces unicellular basidia on a clamp. This sexual cycle is different from those of the other three known teleomorphic species in the Erythrobasidium lineage.

Occultifur externus and six Rhodotorula species (Rhodotorula armeniaca, Rhodotorula aurantiaca, Rhodotorula laryngis, Rhodotorula pallida, Rhodotorula marina and Rhodotorula slooffiae), which were placed in the Erythrobasidium lineage in the large subunit (LSU) rDNA-based tree (Fell et al., 2000), were not included in the analysis of $18 \mathrm{~S}$ rDNA sequences in this study. However, in the LSU rDNA-based tree (Fell et al., 2000), Occultifur externus, Rhodotorula laryngis, Rhodotorula pallida and Rhodotorula slooffiae clustered with Rhodotorula minuta (bootstrap value of $100 \%$ ), Rhodotorula armeniaca and Rhodotorula aurantiaca clustered with Sporobolomyces kluyverinielii, Sporobolomyces phyllomatis and Sporobolomyces salicinus (bootstrap value of $99 \%$ ) and Rhodotorula marina clustered with Sporobolomyces gracilis (bootstrap value of $95 \%$ ). As mentioned above, our four species formed a monophyletic cluster in the Erythrobasidium lineage based on $18 \mathrm{~S}$ rDNA sequences. Therefore, our four species were considered to be phylogenetically separated from Occultifur externus and the six Rhodotorula species.

All the data presented here, therefore, support the conclusion that the teleomorphic species belongs to a new teleomorphic genus, for which we propose the name Bannoa gen. nov., as Bannoa hahajimensis sp. nov., with a multiallelic bipolar mating system. Moreover, we propose three novel Sporobolomyces species for our anamorphs, which are phylogenetically closely related to the genus Bannoa: Sporobolomyces bischofiae sp. nov., Sporobolomyces ogasawarensis sp. nov. and Sporobolomyces syzygii sp. nov. As shown in Table 2, the seven species containing Q-10 $\left(\mathrm{H}_{2}\right)$ in the Erythrobasidium lineage can also be distinguished by their phenotypic characteristics.

\section{Latin diagnosis of Bannoa Hamamoto gen. nov.}

Genus ad Urediniomyces pertinens. Coloniae rubroaurantiaca. Cellulae sphaericae vel ovoideae singulae aut binae. Ballistosporae ovoideae vel ellipsoideae. Pseudomycelium absens. Mycelium secundum copula- 
Table 2. Physiological and biochemical characteristics that differentiate species containing Q-10 $\left(\mathrm{H}_{2}\right)$

Species are listed as: 1, Bannoa hahajimensis; 2, Erythrobasidium hasegawianum; 3 , Sporobolomyces bischofiae; 4, Sporobolomyces elongatus; 5, Sporobolomyces ogasawarensis; 6 , Sporobolomyces syzygii; 7, Sporobolomyces yunnanensis. Characters are scored as: +, positive; - , negative; v, variable.

\begin{tabular}{|lccccccc|}
\hline Characteristic & $\mathbf{1}$ & $\mathbf{2}$ & $\mathbf{3}$ & $\mathbf{4}$ & $\mathbf{5}$ & $\mathbf{6}$ & $\mathbf{7}$ \\
\hline Assimilation of: & & & & & & & \\
L-Arabinose & + & + & - & + & + & + & + \\
L-Rhamnose & + & - & - & + & $\mathrm{V}$ & + & - \\
D-Glucitol & + & + & + & + & + & - & - \\
Methyl $\alpha$-D-glucoside & $\mathrm{V}$ & - & - & - & - & + & - \\
2-Ketogluconate & + & + & + & - & + & + & + \\
Nitrate & - & + & - & - & - & - & + \\
L-Lysine & + & + & + & - & + & + & - \\
G + C content $(\mathrm{mol} \%)$ & $47 \cdot 6-48 \cdot 1$ & $50 \cdot 0$ & $49 \cdot 6$ & $55 \cdot 0$ & $51 \cdot 5-52 \cdot 0$ & $48 \cdot 9$ & $50 \cdot 0$ \\
\hline
\end{tabular}

tionen cellularum productur, cum septis nodosis. Probasidia (teliosporae) non formantur. Basidia unicellulosa basi cum fibulae. Fermentatio nulla. Ureum hydrolysatur. Deoxyribonucleasum extracellulosum positivum. Diazonium caeruleum B positivum. Xylosum in cellulis absens. Systema ubiquinoni majus: Q-10 $\left(\mathrm{H}_{2}\right)$. Species typica: Bannoa hahajimensis Hamamoto, Thanh \& Nakase.

\section{Description of Bannoa Hamamoto gen. nov.}

Bannoa (Ban'no.a. N.L. fem. n. Bannoa of Banno, in honour of I. Banno, for his pioneering work on the teleomorphic life cycle of basidiomycetous yeasts).

The genus is placed in the class Urediniomyces. Colonies are orange to salmon-red. Cells are spherical to ovoid, single or in pairs. Ballistoconidia are ovoidal and ellipsoidal. Pseudomycelium is absent. True mycelium with clamp connections at septa is produced after cell conjugation. Teliospores are not formed. Unicellular basidia arise laterally on a clamp or terminally. Cells of basidia germinate with hyphae, from which yeast cells originate. Sugars are not fermented. Urease and Diazonium blue B reactions are positive. Xylose is absent from whole-cell hydrolysates. The major ubiquinone is Q- $10\left(\mathrm{H}_{2}\right)$.

Type species: Bannoa hahajimensis Hamamoto, Thanh \& Nakase.

\section{Latin diagnosis of Bannoa hahajimensis Hamamoto, Thanh \& Nakase sp. nov.}

In liquido YM post dies $3\left(25^{\circ} \mathrm{C}\right)$, cellulae sphaericae vel ovoideae $(5 \cdot 0-7 \cdot 0 \times 8 \cdot 0-12 \cdot 0 \mu \mathrm{m})$, singulae aut binae. Post 1 mensem sedimentum et pelliculum formantur. Cultura in agaro YM post 1 mensem $\left(25^{\circ} \mathrm{C}\right)$, aurantiaca, glabra aut rugosa, butyracea et margine glabra.
Pseudohyphae nullae. Ballistosporae ovoideae vel ellipsoideae, 3.0-6.0 × 7.0-14.0 $\mu \mathrm{m}$. Mycelium secundum copulationen cellularum (A1 et $\mathrm{A} 2, \mathrm{~A} 2$ et $\mathrm{A} 3, \mathrm{~A} 3$ et $\mathrm{A} 1$ ) productur, cum septis nodosis. Probasidia (teliosporae) non formantur. Basidia unicellulosa basi cum fibulae. Fermentatio nulla. Glucosum, galactosum, L-sorbosum, saccharosum, maltosum, cellobiosum, trehalosum, melibiosum, raffinosum, melezitosum, amylum, D-xylosum, L-arabinosum, D-arabinosum (varium), D-ribosum (varium), L-rhamnosum, ethanolum (varium), glycerolum, ribitolum (varium), galactitolum (varium), D-mannitolum, D-glucitolum, methyl $\alpha$-D-glucosidum (varium), salicinum, glucono- $\delta$-lactonum (varium), acidum 2-ketogluconicum, acidum 5-ketogluconicum, DL-lacticum (varium), acidum succinicum, acidum citricum et acidum D-glucuronicum assimilantur, at non lactosum, inulinum, erythritolum, inositolum nec acidum D-galacturonicum. Lysinum assimilatur at non kalium nitricum, natrium nitrosum, ethylaminum nec cadaverinum. Maxima temperatura crescentiae: $28-29^{\circ} \mathrm{C}$. Ad crescentiam acidum p-aminobenzoicum (varium) et thiaminum necessarium est. Materia amyloidea iodophila non formantur. Ureum hydrolysatur. Diazonium caeruleum B: positivum. Proportio molaris guanini + cytosini in acido deoxyribonucleinico: 47.6-48.1 mol\% (per HPLC). Ubiquinonum majus: Q-10 $\left(\mathrm{H}_{2}\right)$. Xylosum in cellulis absens. Typus stirps $\mathrm{OK}-248^{\mathrm{T}}$ ex folio Bryophyllum pinnatum, Japonia, isolata est. In collectionibus culturarum quas Japan Collection of Microorganisms, Wako, Saitama sustentant, no. JCM $10336^{\mathrm{T}}$ deposita est.

\section{Description of Bannoa hahajimensis Hamamoto, Thanh \& Nakase sp. nov.}

Bannoa hahajimensis (ha.ha.ji.men'sis. N.L. adj. hahajimensis referring to Haha-jima, one of the Japanese Ogasawara Islands in the Pacific Ocean, where the type strain was isolated). 

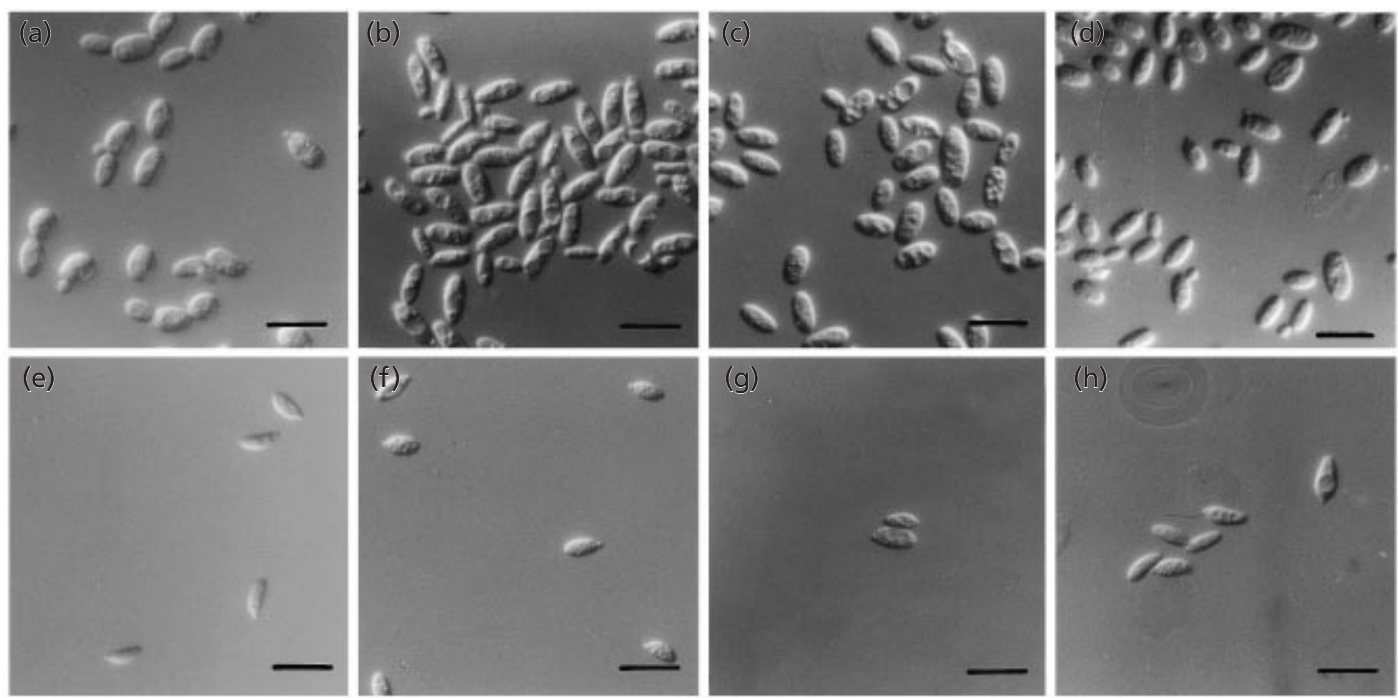

Fig. 4. Photomicrographs of vegetative cells on YM agar (a-d) and ballistoconidia on corn meal agar (e-h). (a, e) Bannoa hahajimensis OK-248 ${ }^{\top}$ (= JCM 10336 $)$. (b, f) Sporobolomyces bischofiae OK-257 $\left(=\mathrm{JCM} 10338^{\top}\right)$. $(c, g)$ Sporobolomyces

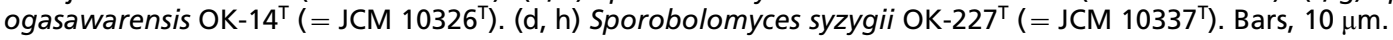

After growth in YM broth (Difco) for 3 days at $25^{\circ} \mathrm{C}$, cells are spherical to ovoid $(5 \cdot 0-7 \cdot 0 \times 8 \cdot 0-12 \cdot 0 \mu \mathrm{m})$, single or in pairs (Fig. 4a). A sediment and a hydrophobic pellicle are formed after 1 month. After growth on YM agar (Difco) at $25^{\circ} \mathrm{C}$ for 3 days, the streak culture is orange. After 1 month, the streak culture is red-orange, smooth, shining, butyrous and soft and has an entire margin. No pseudomycelium develops on Dalmau plate cultures on corn meal agar after 10 days at $25^{\circ} \mathrm{C}$. Ballistoconidia are formed on corn meal agar and YM agar. They are ovoidal and ellipsoidal, 3.0-6.0 $\times 7 \cdot 0-14 \cdot 0 \mu \mathrm{m}$ (Fig. 4e). True mycelium with clamp connections at septa is produced after cell conjugation $(\mathrm{A} 1 \times \mathrm{A} 2, \mathrm{~A} 2 \times \mathrm{A} 3$ and $\mathrm{A} 3 \times \mathrm{A} 1)$. Teliospores are not formed. Unicellular basidia arise laterally on a clamp, sometimes terminally. Germination of basidia occurs by the formation of hyphae. Does not ferment D-glucose. Assimilates D-glucose, galactose, L-sorbose, sucrose, maltose, cellobiose, trehalose, melibiose, raffinose, melezitose, soluble starch, D-xylose, L-arabinose, D-arabinose (variable), D-ribose (variable), L-rhamnose, ethanol (variable), glycerol, ribitol (variable), galactitol (variable), Dmannitol, D-glucitol, methyl $\alpha$-D-glucoside (variable), salicin, glucono- $\delta$-lactone (variable), 2-ketogluconic acid, 5-ketogluconic acid, DL-lactic acid (variable), succinic acid, citric acid and D-glucuronic acid. Does not assimilate lactose, inulin, erythritol, inositol or D-galacturonic acid. Assimilates L-lysine. Does not assimilate nitrate, nitrite, ethylamine or cadaverine. Maximum growth temperature is $28-29{ }^{\circ} \mathrm{C}$. Growth does not occur in vitamin-free medium. $p$-Aminobenzoic acid (variable) and thiamin are required for growth. Growth does not occur on $50 \%$ (w/w) glucose/yeast extract agar. No starch-like substrate is produced. Xylose is absent from whole-cell hydroly- sates. Urease and Diazonium blue $\mathrm{B}$ reactions are positive. The major ubiquinone is $\mathrm{Q}-10\left(\mathrm{H}_{2}\right)$. The $\mathrm{G}+\mathrm{C}$ content of the nuclear DNA is $47 \cdot 6-48 \cdot 1 \mathrm{~mol} \%$, as determined by HPLC. The type strain is strain OK$248^{\mathrm{T}}\left(=\mathrm{JCM} 10336^{\mathrm{T}}=\mathrm{CBS} 9039^{\mathrm{T}}\right)$.

\section{Latin diagnosis of Sporobolomyces bischofiae Hamamoto, Thanh \& Nakase sp. nov.}

In liquido $\mathrm{YM}$ post dies $3\left(25^{\circ} \mathrm{C}\right)$, cellulae sphaericae vel ovoideae $(3.0-4.0 \times 9 \cdot 0-12.0 \mu \mathrm{m})$, singulae aut binae. Post 1 mensem sedimentum et pelliculum formantur. Cultura in agaro $\mathrm{YM}$ post 1 mensem $\left(25^{\circ} \mathrm{C}\right)$, aurantiaca, glabra aut rugosa, butyracea et margine glabra. Pseudohyphae nullae. Ballistosporae ovoideae vel ellipsoideae, $4 \cdot 0-5 \cdot 0 \times 8 \cdot 0-10 \cdot 0 \mu \mathrm{m}$. Fermentatio nulla. Glucosum, galactosum, L-sorbosum, saccharosum, maltosum, cellobiosum, trehalosum, melibiosum, raffinosum, melezitosum, amylum, D-xylosum, glycerolum, ribitolum, D-mannitolum, D-glucitolum, salicinum, acidum 2-ketogluconicum, acidum 5-ketogluconicum, DL-lacticum, acidum succinicum, acidum citricum et acidum $\mathrm{D}-$ glucuronicum assimilantur, at non lactosum, inulinum, L-arabinosum, D-arabinosum, D-ribosum, L-rhamnosum, ethanolum, erythritolum, galactitolum, methyl $\alpha$-D-glucosidum, glucono- $\delta$-lactonum, inositolum nec acidum D-galacturonicum. Lysinum assimilatur at non kalium nitricum, natrium nitrosum, ethylaminum nec cadaverinum. Maxima temperatura crescentiae: 29$30{ }^{\circ} \mathrm{C}$. Ad crescentiam thiaminum necessarium est. Materia amyloidea iodophila non formantur. Ureum hydrolysatur. Diazonium caeruleum B: positivum. Proportio molaris guanini + cytosini in acido deoxyribonucleinico: $49.6 \mathrm{~mol} \%$ (per HPLC). Ubiquinonum majus: Q-10 $\left(\mathrm{H}_{2}\right)$. Xylosum in cellulis absens. Typus stirps OK-257 $7^{\mathrm{T}}$ ex folio Bischofia javanica, Japonia, 
isolata est. In collectionibus culturarum quas Japan Collection of Microorganisms, Wako, Saitama sustentant, no. JCM $10338^{\mathrm{T}}$ deposita est.

\section{Description of Sporobolomyces bischofiae Hamamoto, Thanh \& Nakase sp. nov.}

Sporobolomyces bischofiae [bi.scho'fi.a.e. N.L. gen. n. bischofiae of Bischofia (Bischofia javanica), the plant from which the type strain was isolated].

After growth in YM broth (Difco) for 3 days at $25^{\circ} \mathrm{C}$, cells are spherical to ovoid $(3 \cdot 0-4 \cdot 0 \times 9 \cdot 0-12.0 \mu \mathrm{m})$, single or in pairs (Fig. 4b). A sediment and a hydrophobic pellicle are formed after 1 month. After growth on YM agar (Difco) at $25^{\circ} \mathrm{C}$ for 3 days, the streak culture is orange to salmon-red. After 1 month, the streak culture is brownish orange, smooth, shining, butyrous and soft and has an entire margin. No true mycelium or pseudomycelium develops on Dalmau plate cultures on corn meal agar after 10 days at $25^{\circ} \mathrm{C}$. Ballistoconidia are formed on corn meal agar and YM agar. They are ovoidal and ellipsoidal, 4.0-5.0 $\times$ 8.0-10.0 $\mu \mathrm{m}$ (Fig. 4f). Does not ferment D-glucose. Assimilates D-glucose, galactose, L-sorbose, sucrose, maltose, cellobiose, trehalose, melibiose, raffinose, melezitose, soluble starch, D-xylose, glycerol, ribitol, D-mannitol, D-glucitol, salicin, 2-ketogluconic acid, 5ketogluconic acid, DL-lactic acid, succinic acid, citric acid and D-glucuronic acid. Does not assimilate lactose, inulin, L-arabinose, D-arabinose, D-ribose, Lrhamnose, ethanol, erythritol, galactitol, methyl $\alpha$-Dglucoside, glucono- $\delta$-lactone, inositol or D-galacturonic acid. Assimilates L-lysine. Does not assimilate nitrate, nitrite, ethylamine or cadaverine. Maximum growth temperature is $29-30{ }^{\circ} \mathrm{C}$. Growth does not occur in vitamin-free medium. Thiamin is required for growth. Growth does not occur on $50 \%$ (w/w) glucose/yeast extract agar. No starch-like substrate is produced. Xylose is absent from whole-cell hydrolysates. Urease and Diazonium blue $B$ reactions are positive. The major ubiquinone is Q- $10\left(\mathrm{H}_{2}\right)$. The $\mathrm{G}+\mathrm{C}$ content of the nuclear DNA is $49.6 \mathrm{~mol} \%$, as determined by HPLC. The type strain is strain OK $-257^{\mathrm{T}}$ $\left(=\mathrm{JCM} 10338^{\mathrm{T}}=\mathrm{CBS} 9041^{\mathrm{T}}\right)$.

\section{Latin diagnosis of Sporobolomyces ogasawarensis Hamamoto, Thanh \& Nakase sp. nov.}

In liquido $\mathrm{YM}$ post dies $3\left(25^{\circ} \mathrm{C}\right)$, cellulae sphaericae vel ovoideae $(4 \cdot 0-6 \cdot 0 \times 8 \cdot 0-10 \cdot 0 \mu \mathrm{m})$, singulae aut binae. Post 1 mensem pellicula imperfecta et sedimentum formantur. Cultura in agaro YM post 1 mensem $\left(25^{\circ} \mathrm{C}\right)$, rubro-aurantiaca, glabra aut rugosa, butyracea et margine glabra. Pseudohyphae nullae. Ballistosporae ovoideae vel ellipsoideae, 3.0-6.0 ×6.0-14.0 $\mu \mathrm{m}$. Fermentatio nulla. Glucosum, galactosum, L-sorbosum, saccharosum, maltosum, cellobiosum (varium), trehalosum, lactosum (varium), melibiosum (varium), raffinosum, amylum, D-xylosum, L-arabinosum, D-arabinosum (varium), L-rhamnosum (varium), glycerolum, ribitolum (varium), galactitolum (varium), D-mannitolum, D-glu- citolum, salicinum, glucono- $\delta$-lactonum, acidum 2-ketogluconicum, acidum 5-ketogluconicum, DL-lacticum (varium), acidum succinicum, acidum citricum (varium), inositolum (varium) et acidum D-glucuronicum assimilantur, at non, inulinum, D-ribosum, ethanolum, erythritolum, methyl $\alpha$-D-glucosidum, nec acidum D-galacturonicum. Lysinum assimilatur at non kalium nitricum, natrium nitrosum, ethylaminum nec cadaverinum. Maxima temperatura crescentiae: $29-32{ }^{\circ} \mathrm{C}$. Ad crescentiam acidum p-aminobenzoicum necessarium (varium) et thiaminum (varium) est. Materia amyloidea iodophila non formantur. Ureum hydrolysatur. Diazonium caeruleum B: positivum. Proportio molaris guanini + cytosini in acido deoxyribonucleinico: $51 \cdot 5-52 \cdot 0 \mathrm{~mol} \%$ (per HPLC). Ubiquinonum majus: Q-10 $\left(\mathrm{H}_{2}\right)$. Xylosum in cellulis absens. Typus stirps $\mathrm{OK}-14^{\mathrm{T}}$ ex folio Schima mertensiana, Japonia, isolata est. In collectionibus culturarum quas Japan Collection of Microorganisms, Wako, Saitama sustentant, no. JCM $10326^{\mathrm{T}}$ deposita est.

\section{Description of Sporobolomyces ogasawarensis Hamamoto, Thanh \& Nakase sp. nov.}

Sporobolomyces ogasawarensis (o.ga.sa.war.en'sis. N.L. adj. ogasawarensis referring to Ogasawara, the isolated Japanese islands in the Pacific Ocean where the type strain was isolated).

After growth in YM broth (Difco) for 3 days at $25^{\circ} \mathrm{C}$, cells are spherical to ovoid $(4 \cdot 0-6 \cdot 0 \times 8 \cdot 0-10 \cdot 0 \mu \mathrm{m})$, single or in pairs (Fig. 4c). A sediment and an incomplete ring are formed after 1 month. After growth on YM agar (Difco) at $25^{\circ} \mathrm{C}$ for 3 days, streak culture is orange to salmon-red. After 1 month, streak culture is brownish orange, smooth, shining, butyrous and soft and has an entire margin. No true mycelium or pseudomycelium develops on Dalmau plate cultures on corn meal agar after 10 days at $25^{\circ} \mathrm{C}$. Ballistoconidia are formed on corn meal agar and YM agar. They are ovoidal and ellipsoidal, 3.0-6.0 $6.0-14 \cdot 0 \mu \mathrm{m}$ (Fig. 4g). Does not ferment D-glucose. Assimilates Dglucose, galactose, L-sorbose, sucrose, maltose, cellobiose (variable), trehalose, lactose (variable), melibiose (variable), raffinose, soluble starch, D-xylose, L-arabinose, D-arabinose (variable), L-rhamnose (variable), glycerol, ribitol (variable), galactitol (variable), D-mannitol, D-glucitol, salicin, glucono- $\delta$-lactone, 2 ketogluconic acid, 5-ketogluconic acid, DL-lactic acid (variable), succinic acid, citric acid (variable), inositol (variable) and D-glucuronic acid. Does not assimilate inulin, D-ribose, ethanol, erythritol, methyl $\alpha$-D-glucoside or D-galacturonic acid. Assimilates L-lysine. Does not assimilate nitrate, nitrite, ethylamine or cadaverine. Maximum growth temperature is 29$32{ }^{\circ} \mathrm{C}$. Growth does not occur in vitamin-free medium. p-Aminobenzoic acid (variable) and thiamin (variable) are required for growth. Growth does not occur on $50 \%(\mathrm{w} / \mathrm{w})$ glucose/yeast extract agar. No starch-like substrate is produced. Xylose is absent from whole-cell hydrolysates. Urease and Diazonium blue B reactions are positive. The major ubiquinone is $\mathrm{Q}-10\left(\mathrm{H}_{2}\right)$. The 
$\mathrm{G}+\mathrm{C}$ content of the nuclear DNA is $51.5-52.0 \mathrm{~mol} \%$, as determined by HPLC. The type strain is strain OK$14^{\mathrm{T}}\left(=\mathrm{JCM} 10326^{\mathrm{T}}=\right.$ CBS $\left.9038^{\mathrm{T}}\right)$.

\section{Latin diagnosis of Sporobolomyces syzygii Hamamoto, Thanh \& Nakase sp. nov.}

In liquido $\mathrm{YM}$ post dies $3\left(25^{\circ} \mathrm{C}\right)$, cellulae sphaericae vel ovoideae $(4.0-6.0 \times 6 \cdot 0-10 \cdot 0 \mu \mathrm{m})$, singulae aut binae. Post 1 mensem pellicula imperfecta et sedimentum formantur. Cultura in agaro YM post 1 mensem $\left(25^{\circ} \mathrm{C}\right)$, aurantiaca, glabra aut rugosa, butyracea et margine glabra. Pseudohyphae nullae. Ballistosporae ovoideae vel ellipsoideae, 3.0-5.0 $\times$ 8.0-10.0 $\mu \mathrm{m}$. Fermentatio nulla. Glucosum, galactosum, L-sorbosum, saccharosum, maltosum, cellobiosum, trehalosum, melibiosum, raffinosum, melezitosum, amylum, D-xylosum, L-arabinosum, L-rhamnosum, glycerolum, ribitolum, D-mannitolum, D-glucitolum, methyl $\alpha$-D-glucosidum, salicinum, glucono- $\delta$-lactonum, acidum 2-ketogluconicum, acidum 5-ketogluconicum, DL-lacticum, acidum succinicum, acidum citricum, et acidum D-glucuronicum assimilantur, at non lactosum, inulinum, D-arabinosum, D-ribosum, ethanolum, erythritolum, galactitolum, inositolum nec D-galacturonicum. Lysinum assimilatur at non kalium nitricum, natrium nitrosum, ethylaminum nec cadaverinum. Maxima temperatura crescentiae: $29-30{ }^{\circ} \mathrm{C}$. Ad crescentiam acidum p-aminobenzoicum et thiaminum necessarium est. Materia amyloidea iodophila non formantur. Ureum hydrolysatur. Diazonium caeruleum B: positivum. Proportio molaris guanini + cytosini in acido deoxyribonucleinico: $48.9 \mathrm{~mol} \%$ (per HPLC). Ubiquinonum majus: Q-10 $\left(\mathrm{H}_{2}\right)$. Xylosum in cellulis absens. Typus stirps OK-227 $7^{\mathrm{T}}$ ex folio Syzygium buxifolium, Japonia, isolata est. In collectionibus culturarum quas Japan Collection of Microorganisms, Wako, Saitama sustentant, no. JCM $10337^{\mathrm{T}}$ deposita est.

\section{Description of Sporobolomyces syzygii Hamamoto, Thanh \& Nakase sp. nov.}

Sporobolomyces syzygii [sy.zy'gi.i. N.L. gen. n. syzygii of Syzygium (Syzygium buxifolium), the plant from which the type strain was isolated].

After growth in YM broth (Difco) for 3 days at $25^{\circ} \mathrm{C}$, the cells are spherical to ovoid $(4.0-6.0 \times 6.0-10.0 \mu \mathrm{m})$, single or in pairs (Fig. 4d). A sediment and an imperfect ring are formed after 1 month. After growth on YM agar (Difco) at $25^{\circ} \mathrm{C}$ for 3 days, the streak culture is orange. After 1 month, the streak culture is brownish orange, smooth, shining, butyrous and soft and has an entire margin. No true mycelium or pseudomycelium develops on Dalmau plate cultures on corn meal agar after 10 days at $25^{\circ} \mathrm{C}$. Ballistoconidia are formed on corn meal agar and YM agar. They are ovoidal and ellipsoidal, 3.0-5.0 $\times 8 \cdot 0-10 \cdot 0 \mu \mathrm{m}$ (Fig. 4h). Does not ferment D-glucose. Assimilates D-glucose, galactose, Lsorbose, sucrose, maltose, cellobiose, trehalose, melibiose, raffinose, melezitose, soluble starch, D-xylose, Larabinose, L-rhamnose, glycerol, ribitol, D-mannitol,
D-glucitol, methyl $\alpha$-D-glucoside, salicin, glucono- $\delta$ lactone, 2-ketogluconic acid, 5-ketogluconic acid, DLlactic acid, succinic acid, citric acid and D-glucuronic acid. Does not assimilate lactose, inulin, D-arabinose, D-ribose, ethanol, erythritol, galactitol, inositol or Dgalacturonic acid. Assimilates L-lysine. Does not assimilate nitrate, nitrite, ethylamine or cadaverine. Maximum growth temperature is $29-30^{\circ} \mathrm{C}$. Growth does not occur in vitamin-free medium. $p$-Aminobenzoic acid and thiamin are required for growth. Growth does not occur on $50 \%$ (w/w) glucose/yeast extract agar. No starch-like substrate is produced. Xylose is absent from whole-cell hydrolysates. Urease and Diazonium blue $\mathrm{B}$ reactions are positive. The major ubiquinone is Q-10 $\left(\mathrm{H}_{2}\right)$. The $\mathrm{G}+\mathrm{C}$ content of the nuclear DNA is $48.9 \mathrm{~mol} \%$, as determined by HPLC. The type strain is strain OK $-227^{\mathrm{T}}(=\mathrm{JCM}$ $\left.10337^{\mathrm{T}}=\operatorname{CBS} 9040^{\mathrm{T}}\right)$.

\section{ACKNOWLEDGEMENTS}

We thank Dr Toyozo Sato, Shikoku National Agricultural Experiment Station, Japan, for kindly supplying plant materials collected in the Ogasawara Islands.

\section{REFERENCES}

Bai, F.-Y., Takashima, M., Hamamoto, M. \& Nakase, T. (2001). Sporobolomyces yunnanensis sp. nov., a Q-10 $\left(\mathrm{H}_{2}\right)$-containing yeast species with a close phylogenetic relationship to Erythrobasidium hasegawianum. Int J Syst Evol Microbiol 51, 231-235.

Berbee, M. L., Yoshimura, A., Sugiyama, J. \& Taylor, J. W. (1995). Is Penicillium monophyletic? An evaluation of phylogeny in the family Trichomaceae from 18S, 5.8S and ITS ribosomal DNA sequence data. Mycologia 87, 210-222.

Boekhout, T. \& Nakase, T. (1998). Sporobolomyces Kluyver \& van Niel. In The Yeasts, a Taxonomic Study, 4th edn, pp. 828-843. Edited by C. P. Kurtzman \& J. W. Fell. Amsterdam: Elsevier.

Cech, T. R. (1988). Conserved sequences and structures of group I introns: building an active site for RNA catalysis - a review. Gene 73, 259-271.

Fell, J. W. \& Statzell-Tallman, A. (1998). Rhodosporidium Banno. In The Yeasts, a Taxonomic Study, 4th edn, pp. 678-692. Edited by C. P. Kurtzman \& J. W. Fell. Amsterdam: Elsevier.

Fell, J. W., Hunter, I. L. \& Tallman, A. S. (1973). Marine basidiomycetous yeasts (Rhodosporidium spp. n.) with tetrapolar and multiple allelic bipolar mating systems. Can J Microbiol 19, 643-657.

Fell, J. W., Boekhout, T., Fonseca, A., Scorzetti, G. \& StatzellTallman, A. (2000). Biodiversity and systematics of basidiomycetous yeasts as determined by large-subunit rDNA D1/D2 domain sequence analysis. Int J Syst Evol Microbiol 50, 1351-1371.

Felsenstein, J. (1985). Confidence limits on phylogenies: an approach using the bootstrap. Evolution 39, 783-791.

Felsenstein, J. (1995). PHYLIP (phylogeny inference package), version 3.57c. Seattle: Department of Genetics, University of Washington.

Hamamoto, M. \& Nakase, T. (1995). Ballistosporous yeasts found on the surface of plant materials collected in New Zealand. 1. Six new species in the genus Sporobolomyces. Antonie Leeuwenhoek 67, 151-171.

Hamamoto, M. \& Nakase, T. (2000). Phylogenetic analysis of the ballistoconidium-forming yeast genus Sporobolomyces based on $18 \mathrm{~S}$ rDNA sequences. Int J Syst Evol Microbiol 50, 1373-1380.

Hamamoto, M., Sugiyama, J. \& Komagata, K. (1988). Transfer of Rhodotorula hasegawae to a new basidiomycetous genus Erythrobasidium as Erythrobasidium hasegawae comb. nov. J Gen Appl Microbiol 34, 279-287. 
Hamamoto, M., Tamura, M. \& Nakase, T. (2000). Emended descriptions of Tilletiopsis washingtonensis, Tilletiopsis cremea and Tilletiopsis lilacina. Int J Syst Evol Microbiol 50, 925-930.

Itoh, T., Kudo, T., Parenti, F. \& Seino, A. (1989). Amended description of the genus Kineosporia, based on chemotaxonomic and morphological studies. Int J Syst Bacteriol 39, 168-173.

James, S. A., Collins, M. D. \& Roberts, I. N. (1996). Use of an rRNA internal transcribed spacer region to distinguish phylogenetically closely related species of the genera Zygosaccharomyces and Torulaspora. Int $J$ Syst Bacteriol 46, 189-194.

Nagahama, T., Hamamoto, M., Nakase, T. \& Horikoshi, K. (1999). Kluyveromyces nonfermentans sp. nov., a new yeast species isolated from the deep sea. Int J Syst Bacteriol 49, 1899-1905.

Nakase, T. \& Suzuki, M. (1985). Ballistospore-forming yeasts found on the surface of the Japan rice plant, Oryza sativa L. J Gen Appl Microbiol 31, 457-474.

Nakase, T. \& Suzuki, M. (1986). The ubiquinone system in strains of species in the ballistospore-forming yeast genera Sporidiobolus, Sporobolomyces and Bullera. J Gen Appl Microbiol 32, 251-258.

Nakase, T. \& Takashima, M. (1993). A simple procedure for the high frequency isolation of new taxa of ballistosporous yeasts living on the surface of plants. RIKEN Rev 3, 33-34.

Oda, Y., Yabuki, M., Tonomura, K. \& Fukunaga, M. (1997). Reexamination of yeast strains classified as Torulaspora delbrueckii (Lindner). Int J Syst Bacteriol 47, 1102-1106.

Robbins, W. J. \& Ma, R. (1944). A Rhodotorula deficient for paraamino-benzoic acid. Science 100, 85-86.

Saitou, N. \& Nei, M. (1987). The neighbor-joining method: a new method for reconstructing phylogenetic trees. Mol Biol Evol 4, 406-425.

Sampaio, J. P., Bauer, R., Begerow, D. \& Oberwinkler, F. (1999). Occultifur externus sp. nov., a new species of simple-pored auricularioid heterobasidiomycete from plant litter in Portugal. Mycologia 91, 1094-1101.

Shivas, R. G. \& Rodrigues de Miranda, L. (1983). Two new species of the genus Sporobolomyces and a new Rhodotorula species from leaf surfaces. Antonie Leeuwenhoek 49, 159-165.

Sugiyama, J. \& Hamamoto, M. (1998). Erythrobasidium Hamamoto, Sugiyama \& Komagata. In The Yeasts, a Taxonomic Study, 4th edn, pp. 654-655. Edited by C. P. Kurtzman \& J. W. Fell. Amsterdam: Elsevier.

Thompson, J. D., Higgins, D. G. \& Gibson, T. J. (1994). Clustal w: improving the sensitivity of progressive multiple sequence alignment through sequence weighting, position-specific gap penalties and weight matrix choice. Nucleic Acids Res 22, 4673-4680.

Waalwijk, C., de Koning, J. R. A., Baayen, R. P. \& Gams, W. (1996). Discordant groupings of Fusarium spp. from sections Elegans, Liseola and Dlaminia based on ribosomal ITS1 and ITS2 sequences. Mycologia 88, 361-368.

White, T., Bruns, T., Lee, S. \& Taylor, J. W. (1990). Amplification and direct sequencing of fungal ribosomal RNA genes for phylogenetics. In PCR Protocols, pp. 315-322. Edited by M. Innis, D. Gelfand, J. J. Sninsky \& T. J. White. San Diego: Academic Press.

Yamada, Y. \& Kondo, K. (1973). Coenzyme Q system in the classification of the yeast genera Rhodotorula and Cryptococcus and the yeast-like genera Sporobolomyces and Rhodosporidium. J Gen Appl Microbiol 19, 59-77.

Yamada, Y., Kanematsu, Y., Ohashi, M. \& Kondo, K. (1973). On the partly reduced coenzyme Q isolated from " Rhodotorula lactosa" IFO 1058 and its relation to the taxonomic position. Agric Biol Chem 37, 621-628.

Yarrow, D. (1998). Methods for the isolation, maintenance and identification of yeasts. In The Yeasts, a Taxonomic Study, 4th edn, pp. 77-100. Edited by C. P. Kurtzman \& J. W. Fell. Amsterdam: Elsevier. 